\title{
Social representation of domestic violence against women among Nursing Technicians and Community Agents*
}

\author{
Representação social da violência doméstica contra a mulher entre \\ Técnicos de Enfermagem e Agentes Comunitários \\ Representación social de la violencia doméstica contra la mujer \\ entre Técnicos de Enfermería y Agentes Comunitarios
}

Camila Daiane Silva ${ }^{1}$, Vera Lúcia de Oliveira Gomes², Denize Cristina de Oliveira ${ }^{3}$, Sergio Corrêa Marques ${ }^{4}$, Adriana Dora da Fonseca ${ }^{5}$, Sibele da Rocha Martins ${ }^{6}$

\footnotetext{
* Extracted from the dissertation "Representações de Técnicos de Enfermagem e Agentes Comunitários acerca da violência doméstica contra a mulher", Postgraduate Program in Nursing, Universidade Federal do Rio Grande, 2014.

${ }^{1}$ PhD Student, Postgraduate Program in Nursing, Universidade Federal do Rio Grande, Rio Grande, RS, Brazil.

${ }^{2}$ Full Professor, Nursing School, Universidade Federal do Rio Grande, Rio Grande, RS, Brazil.

${ }^{3}$ Full Professor, Nursing Faculty, Universidade do Estado do Rio de Janeiro, Rio de Janeiro, RJ, Brazil.

${ }^{4}$ Adjunct Professor, Nursing Faculty, Universidade do Estado do Rio de Janeiro, Rio de Janeiro, RJ, Brasil.

${ }^{5}$ Associate Professor, Nursing School, Universidade Federal do Rio Grande, Rio Grande, RS, Brasil.

${ }^{6}$ Professor, Nursing School, Universidade Federal do Rio Grande, Rio Grande, RS, Brasil.
}

\begin{abstract}
Objective: To analyze the social representations of the Nursing Technicians and Community Health Agents about domestic violence against women. Method: A qualitative study carried out in the city of Rio Grande, RS, in which evocations and interviews were collected between July and November 2013. For the treatment of data were used the EVOC 2005 software and the context analysis. Results: It is a structured representation, in which the central nucleus contains conceptual, imaging and attitudinal elements, namely: abuse, aggression, physical aggression, cowardice and lack of respect. Such terms were present in the context of the interviews. The professionals acknowledged that violence is not limited to physical aspects and were judgemental about the acts of the aggressor. Conclusion: This knowledge may enable the problematization of the studied phenomenon with the team, and facilitate the search for prevention and intervention strategies for victims, offenders and managers of health services.
\end{abstract}

\section{DESCRIPTORS}

Violence Against Woman; Domestic Violence; Community Health Workers; Nurse's Role; Nursing Care.

\section{Correspondence Addressed to:}

Camila Daiane Silva

Rua Visconde de Paranaguá, 102, Centro

CEP 96203-900 - Rio Grande, RS, Brazil

E-mail: camilad.silva@yahoo.com.br
Received: 05/15/2014

Approved: 11/07/2014 


\section{INTRODUCTION}

The social phenomenon of domestic violence against women (DVAW) has been confronted as a universal problem for its impact on economic, social, educational and health areas. The occurrence of this phenomenon and its consequences for victims and offenders call the attention of the media, researchers, organizations, public and legal bodies. In this sense, the World Health Organization shows that the violence perpetrated by an intimate partner is the most common form, reaching about $30 \%$ of women worldwide ${ }^{(1)}$.

In Africa alone, sexual violence by an intimate partner reaches $45.6 \%$, and in Southeast Asia, $40.2 \%{ }^{(1)}$. In the international ranking of women's homicides between the years 2006 and 2010, the United States of America (USA) occupy the $24^{\text {th }}$ place and France, the $68^{\text {th }}$, while Brazil is in the $7^{\text {th }}$ place ${ }^{(2)}$. In Brazil, since 2006, it has been established the Law No. 11,340, known as Maria da Penha Law, which aims to restrain and prevent domestic and family violence against women ${ }^{(3)}$. The map of violence, published in 2012, reveals that between 1980 and 2010 the number of female homicides in Brazil went from 1,353 to 4,297, which represents an increase of $217.6 \%$. This ranking is led by the state of Espírito Santo, where the rate is 9.8 murders per 100,000 women, followed by the state of Alagoas with 8.3, and Paraná with 6.4. The document also reveals that $71.8 \%$ of the incidents have occurred in the own residence of victims ${ }^{(2)}$. A survey with pregnant women revealed that of 1,120 women registered in the Family Health Program, $25.3 \%$ reported some incident of physical violence with the current partner or the latest partner during the current pregnancy ${ }^{(4)}$.

Although significant, these data do not express the magnitude of the problem, since many reasons keep the violent acts restricted to the household. Sometimes, friends, family, neighbors and the victims themselves naturalize domestic violence against women, not recognizing it as such.

Hence, to prevent a possible naturalization of domestic violence against women, the Family Health Units (FHU) appear as allies in identifying and combating this phenomenon that affects women's health. These units have a minimum team of nurses, physicians, nursing technicians (NT) and Community Health Agents (CHA). A study with CHA identified that they pointed the bonding, listening and dialogue with the victims of violence as essential tools for attention to their needs ${ }^{(5)}$. However, the demand and the limited number of professionals are mentioned as difficulties for achieving that purpose.

Compared to other professionals, there is a greater number of NT and CHA in the teams, which allows them to serve more families and keep a closer contact with them. The NT and CHA are required to have a technical course and high school degree, respectively. This differentiates them from other members of staff, who must have higher education, and such characteristic can generate different representations of the studied phenomenon. The duties of the CHA include carrying out routine home and community actions, which enable knowing the privacy of homes ${ }^{(6)}$. This knowledge can be identified in a study on violence against rural women, in which health professionals, including the $\mathrm{CHA}$, centralized their social representation especially in terms of fear, alcohol and the women's excessive workload ${ }^{(7)}$. The NT can also make home visits and engage with problematic issues of the domestic space. They both make the bridge between the families and the FHU, and this proximity and coexistence can facilitate the detection of domestic violence against women in its various forms.

The social representation is a form of knowledge socially constructed and shared that has a practical purpose and contributes to the construction of a common reality to a social group ${ }^{(8)}$. Supposedly, many professionals represent domestic violence against women solely as the one that leaves physical marks, expressing the other forms as manifestations of jealousy or a simple couple discussion. Furthermore, it is assumed that the social representations of the NT and CHA about domestic violence against women may influence the care provided to victims, as well as the development of preventive and intervention strategies with the victim and the aggressor. The present study aimed to analyze the social representations of the NT and the CHA about domestic violence against women.

Therefore, we adopted the structural approach of the Social Representations Theory as line of reasoning. This approach, also known as the Central Nucleus Theory was proposed by Jean-Claude Abric in $1989^{(9)}$, and understands the social representation organized around a central nucleus $(\mathrm{CN})$ that is stable and resistant to change. The elements of first and second periphery and the contrast elements are essential complements of the $\mathrm{CN}^{(9)}$.

\section{METHOD}

This is a qualitative study carried out in $19 \mathrm{FHU}$ in the city of Rio Grande, state of Rio Grande do Sul, Brazil, with 12 units located in the urban area and seven in rural areas. These units have $40 \mathrm{NT}$ and $178 \mathrm{CHA}$.

The data collection was conducted between July and November 2013, by the techniques of free evocations and in-depth interviews. In total, 154 professionals participated in the first part, being $39 \mathrm{NT}$ and $115 \mathrm{CHA}$. The professionals who were on leave or vacation and those who refused the invitation were excluded. We used the technique of free evocation or association, asking the participants to evoke five words or expressions related to the inductor term domestic violence against women. This technique makes it possible to highlight the true meaning of the studied object in a faster, more spontaneous and dynamic way than the other methods ${ }^{(9)}$.

A total of 39 professionals participated in the interviews, being $12 \mathrm{NT}$ and $27 \mathrm{CHA}$. Among the scholars of social representations there is a consensus that 30 is the minimum quantity to gather the representations in a group through interviews ${ }^{(10)}$. For the selection of the FHU where the interviews should be held, a map was drew up with the geographic location of each unit. Using the criterion of proximity among the FHU, the referred map was divided 
in four parts in the urban area (including $12 \mathrm{FHU}$ ), and six parts in the rural area (including seven FHU). The distance between these units prevented a larger grouping. Believing that similar social representations may result from physical proximity, it was decided to select a FHU by outlined area, i.e., four urban FHU and six rural. At least one NT and two $\mathrm{CHA}$ of these units were invited for the interview.

The interview script included open-ended questions that allowed grasping the general, professional and personal perception about domestic violence against women. On the professional context, were rescued care practices aimed at victimized patients, as well as ethical and legal aspects of this assistance, including the notification and the difficulties with carrying it out. From the personal point of view, was investigated a possible experience of violent situation in the family environment, as well as the action taken. The interviews were conducted individually in a room at the FHU that guaranteed privacy, lasting 40 minutes on average, and were recorded and transcribed.

The data obtained by evocation were analyzed by two techniques. At first, we used the software Ensemble des Programmes Permettant l'Analyse evocations (EVOC) (Group of Programs for the Analysis of Evoked Responses), version 2005 , proposed by Pierre Vergès ${ }^{(11)}$, which adopts as criteria the frequency of occurrence and order of appearance of the evoked terms. This program enables the construction of a frame with four boxes consisting of central elements, first and second peripheral elements and contrast elements ${ }^{(12)}$.

The similarity analysis proposed by Claude Flament in 1986 was performed with the second technique. It is based on the calculation of connectivity between the elements of representation ${ }^{(11-12)}$, and used to check the "amount of links or connections that a given element has with the other elements of the representation" ${ }^{\prime(2)}$. Therefore, was calculated the co-occurrence of constant terms in the frame of four boxes, considering only the individuals who evoked at least two words of the mentioned frame. Subsequently, the cooccurrence table was prepared, the similarity index was calculated and the maximum tree was built.

The interviews were treated by content analysis ${ }^{(13)}$. The context of unit was adopted for the coding. In other words, from the interviews were selected phrases or passages that had some constant elements in the frame of four boxes, built by the analysis of evocations.

The speeches of participants were identified by standardized letters, plus an Arabic number corresponding to the order of collection of evocations. The study followed the ethical standards recommended by Resolution 466/2012 and was approved by the Research Ethics Committee at the Health Area under No 020/2013.

\section{RESULTS}

Of the 154 health professionals, 140 were females and 14 were males. The age ranged from 24 to 65 years, with predominance of the age range of 30 to 39 years, with 59 participants. As for marital status, 104 professionals had a steady partner and lived with them, seven had a partner but did not live together, and 43 had no partner. With regard to the workplace, 113 exercised their activities in FHU of urban areas and 41 in FHU of rural areas. On average, these professionals had two to five years of service in the current FHU and 117 said they had participated in an event on domestic violence against women organized by the unit.

The corpus formed with evocations related to the inductor term domestic violence against women totaled 767 words, of which 226 were different. On a scale of 1 to 5 , the mean of the average orders of evocation (rang) was 3 , the minimum frequency was 11 and the mean frequency, 19. The analysis of this data set resulted in the frame of four boxes (Figure 1).

\begin{tabular}{|c|c|c|c|c|c|}
\hline \multicolumn{3}{|c|}{ Frequency $\geq 19$ / Rang $<3$} & \multicolumn{3}{|c|}{ Frequency $\geq 19$ / Rang $\geq 3$} \\
\hline & Freq. & Rang & & Freq. & Rang \\
\hline Abuse & 19 & 2.263 & Fear & 31 & 3.129 \\
\hline Aggression & 35 & 1.857 & Revolt & 20 & 3.150 \\
\hline Physical agression & 20 & 2.550 & & & \\
\hline Cowardice & 25 & 1.880 & & & \\
\hline Lack of respect & 31 & 2.484 & & & \\
\hline \multicolumn{3}{|c|}{ Frequency $<19$ / Rang $<3$} & \multicolumn{3}{|c|}{ Frequency $<19$ / Rang $\geq 3$} \\
\hline & Freq. & Rang & & Freq. & Rang \\
\hline Abuse of power & 14 & 2.857 & $\begin{array}{l}\text { Low self- } \\
\text { esteem }\end{array}$ & 18 & 3.556 \\
\hline Pain & 12 & 2.417 & Submission & 18 & 3.222 \\
\hline Humiliation & 15 & 2.933 & & & \\
\hline Impunity & 13 & 2.846 & & & \\
\hline Suffering & 14 & 2.643 & & & \\
\hline Sadness & 15 & 2.733 & & & \\
\hline Violence & 11 & 2.545 & & & \\
\hline
\end{tabular}

Figure 1 - Frame of four boxes formed by the evocation of the NT and $\mathrm{CHA}$ in relation to the inductor term domestic violence against women - Rio Grande, RS, 2014.

When seeking the social representations of a group about some phenomenon, it is essential to try to identify the presence of conceptual, imaging and attitudinal dimensions. Therefore, we sought to identify such dimensions in the central nucleus of the representation of the NT and $\mathrm{CHA}$ about the domestic violence against women.

The CN located in the upper-left quadrant is lasting, more resistant to changes and socially determined. In this quadrant are located the most significant terms for the subjects, because they have high frequency and are more promtly evoked.

Thus, the terms aggression, physical aggression, abuse, cowardice and lack of respect were evoked as the possible centrality of representation. The conceptual dimension of this representation is contained in the terms aggression, more frequent and promptly evoked, and physical aggression. The latter also contains the imaging dimension, portraying both the violent act and its consequence, that is, the marks left on the victim's body. The attitude is present in the terms abuse, cowardice and lack of respect and represents the judgement 
of the offender's actions. Therefore, the NT and CHA have a structured representation of domestic violence against women, in which the probable centrality expresses negative aspects related to the offender and the violent act.

It is noteworthy that the $\mathrm{CN}$ should play the evaluative and pragmatic role, and for that, functional and normative elements must coexist in it. The functional elements represented in this study by the terms aggression and physical aggression, are associated with the descriptive characterization and the insertion of the object under study in the social practices. The normative elements contained in the terms abuse, cowardice and lack of respect, are originated from the values system of the individuals, generate attitudes or judgments and decisions about the object. To contextualize the functional and normative elements contained in the $\mathrm{CN}$, we present excerpts from interviews in which they were employed.

It's every type of violence, both the physical aggression as the verbal... (NT-155).

The lack of respect for women, because they think we are the weaker sex... it is the aggression in general (CHA-188).

She said that every time her husband comes home drunk and she says something, she gets beaten up. It is cowardice! (NT-95).

Ascertaining the degree of connectivity of the elements identified as participants in the analyzed representation, the maximum tree (Figure 2) indicates the term aggression, more frequent and promptly evoked, as organizer of the other elements of representation. This term maintains multiple connections with other elements, but the strongest case is with the term physical aggression, also present in the $\mathrm{CN}$ of the four-box frame. It is observed that the similarity analysis reaffirms the participation of the elements aggression and physical aggression in the $\mathrm{CN}$ of the representation. Among the accessory elements, those connected by a low similarity index, stand out the terms sadness, revolt, fear, low self-esteem and submission, pointing to the sentimental sphere. Such connections reflect that the professionals identify the feelings of the victim and sometimes share them.

The peripheral elements are more flexible, located in the upper and lower right quadrant, being the first and second peripheries, respectively. These elements are more accessible,

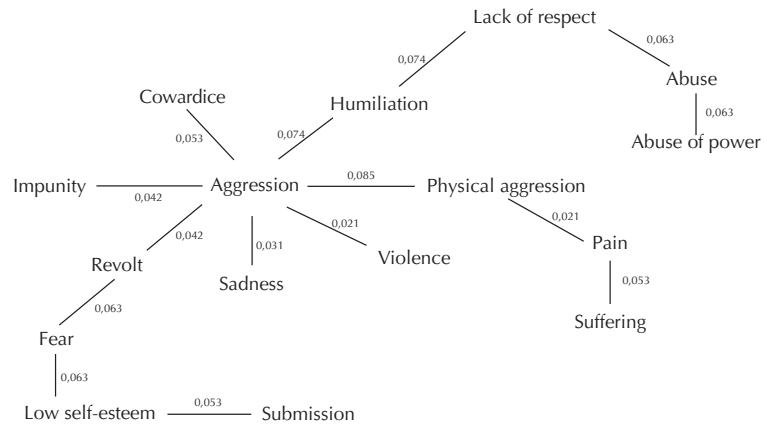

Figure 2 - Maximum tree of similarity analysis of the most frequent evocations in the overall analysis of NT and CHA - Rio Grande, RS, 2014. alive and concrete. The constant terms in the first periphery have high frequency and average order of evocation equal to or greater than 3 . The term fear was the most common and readily evoked, followed by revolt. Fear can refer to the emotional sphere of both the victim as the professional, and revolt is associated with the feeling of the professional in face of the occurrence of violence and the fact that the victims have reconciled with the offender.

\section{If you report, how will I keep working? You work with fear, you cannot do anything. Even more because they say you have to live in the environment where you work, every- one knows who I am, the address! (CHA-13).}

We try to explain to them, here, that they have to report, but they are afraid, there's no way... (NT-95).

Sometimes the person comes totally different on the other day, it is a different version, even if we know that it happened ... that she was assaulted ... on the other day she changes her version, it's revolting! (NT-138).

What I see is the human going back to the time of the caves, when the woman was used as an animal, dragged and abused. Today this cannot happen because it's all very evolved, when I'm faced with such a situation I feel revolted! (CHA-03).

The second periphery is composed of less frequent and less promptly evoked elements. It is the closest interface to representation, with the social practices; it contains the terms submission and low self-esteem at the same frequency. These words show how the professionals view the victims who are immersed in a violent relationship and harmful to health.

Her face deformed, her black eye, the mouth cut in a way impossible to hide with a foundation [makeup to cover the marks], what I said, selfesteem! (CHA-100).

The woman is submissive! She gets a 'no'l from the father, the husband. She said that when he did not drink, he was a good person and I could see the submission there, because he was aggressive only when be drank. (CHA-01).

In the lower-left quadrant are located the contrast elements with low frequency and low order of evocation than average. It comprises the terms: abuse of power, pain, humiliation, impunity, suffering, sadness and violence. The contrast area elements are also considered important, and possibly reinforce the constant ideas contained in the first periphery, or reveal the existence of a minor sub-group with a different representation.

The bumiliation and sadness stand out, both mentioned 15 times. The first promptly evoked term is pain and the second is violence. In this zone, is observed the emotional sphere that is strongly associated with the victims' feelings in face of the violent act. Pain arises both in the psychological sense, and as a result of physical violence. 
I talked to the person, she was in pain. At first, she had fallen... (CHA-79).

I do not know what hurts more; if you see the person or the person who is totally devastated ... (NT-138).

The term suffering refers to the feeling generated in the victim as a result from any form of violence.

I witnessed psychological violence in a relationship I had. It took me a long time to see that I was suffering, when I read a banner we had, I said to myself: - I am suffering from this! (NT-194).

The term sadness rises in the speeches of professionals as their feeling when witnessing a situation of violence between family members or any case attended at the FHU. On the other hand, the term bumiliation refers to the victim and the situations she tolerates from the attacker, even if the victim is a CHA.

It was of sadness, because they didn't have the balance to talk and stay calm. She came very hurt and as I already have this ... [bond] I feel sad, depressed to see these things... (NT-08).

If I bought something that in his view was not necessary, I was putting his money away because who worked and provided for the family was him, a bumiliation! (CHA-03).

The term violence reinforces the conceptual sphere of DVAW, just as aggression and physical aggression in $\mathrm{CN}$. Though not literally mentioned, the meaning of abuse of power is explicit in the context of speeches and materializes the exercise of power that the offender believes to have over his victims.

The owner of the house, the man has the power and we don't! (CHA-10).

It happens a lot, men can do it all and women can't (NT-08).

The NT and CHA subjectively employed the term impunity associating it with the fact that the victims leave their abusers free of punishment, either by not wishing to report or by reporting it and abandoning the idea.

\section{I think it's a pretty big impunity that happens,} that we experience (NT-194).

In their last fight, the police and prosecutor came, my father-in-law was removed from home and what happened? Six months passed... she [mother-in-law] asked him to come back, he's home now and did it all again... (CHA-157).

We compared the elements of the contrast area of all participants with the $\mathrm{CN}$ elements of representation of the professionals working in FHU of the rural area, verifying the common presence of the terms suffering and sadness. Also, by comparing the elements of the contrast area of all participants with the $\mathrm{CN}$ elements of representation of the CHA, was identified the term sadness in common.

\section{DISCUSSION}

The NT and CHA develop activities and actions in the community, during which they can identify the occurrence of domestic violence against women. The care provided to victims can be directed by the representation of domestic violence against women of these professionals. From the analysis of this representation, it is possible to understand and intervene in the care and development of interventions of prevention and inclusion of aggressors in recovery programs. It is noteworthy that a social representation is structured when it contains conceptual, imaging and attitudinal dimensions ${ }^{(14)}$, and that such dimensions were identified in the representation of the NT and CHA about domestic violence against women.

The $\mathrm{CN}$ of a representation is connected to "the historical, sociological and ideological conditions, directly related to the values and norms by defining the fundamental principles around which the representations are constituted ${ }^{\prime(9)}$. The terms aggression and physical aggression, present in this quadrant, in addition to indicating the conceptual and imaging dimension of representation, show that the occurrence of physical forms of violence leaves marks on the body of victims, and even if unwanted, the situation is exposed. The similarity analysis ${ }^{(11)}$ reiterates the connection between these two terms, aggression and physical aggression.

These two terms are also part of the representation central nucleus of health professionals (including the $\mathrm{CHA}$ ) about violence against rural women ${ }^{(7)}$. A study identifies that in a hospital in Angola, the suspected occurrence of violence is identified mainly by physical injuries such as burns and fractures ${ }^{(15)}$. Another study states that if the victims have physical injuries, there is a greater probability of health professionals identifying the intimate partner violence, although the victims can receive treatment without being questioned about the cause ${ }^{(16)}$. The generalized term aggression is used by professionals to possibly embrace the other forms of psychological, patrimonial, moral and sexual violence ${ }^{(3)}$, even if these are not discriminated as such by them.

Although physical violence is the most easily recognized, psychological violence is the most frequent ${ }^{(17-18)}$ and a practice carried out in the form of threats, control and scenes of jealousy ${ }^{(18)}$. On the other hand, a study carried out in a state of India points out that the most common type is the combination of physical and emotional violence, followed by physical violence alone ${ }^{(19)}$. Regardless of the embodiment of violence, health professionals can play an important role in the early identification of the problem, thus reducing its consequences and the likelihood of victimization $^{(16)}$.

The terms abuse, lack of respect and cowardice are related to the judgments of professionals regarding the offender's actions. In this sense, a study carried out with managers, nurses, doctors and community health agents identified the terms lack of respect and cowardice in the second periphery, in the central nucleus of the representation ${ }^{(7)}$. 
The peripheral elements 'are the interface between the central nucleus and the concrete situation in which the representation is produced or put into operation ${ }^{(9)}$. The transformation of a representation is given by modifying the peripheral system elements, since in it 'the contradictions may appear and be tolerated ${ }^{\prime}{ }^{(9)}$. In the first periphery, the terms revolt and fear arise. The feelings of fear of the offender's reaction, impotence and uncertainty permeate the professional performance ${ }^{(20)}$. The participants of this study share these feelings, especially the CHA, because they reside in the community where they work. On the one hand, it facilitates the approach and the bond with families, but on the other, it can hinder the care process.

In face of the assumed or established violence, the team needs to act with caution from the screening, directing the questions to clarify the origin of certain signs or symptoms ${ }^{(16)}$. This caution involves since choosing an appropriate space for assisting the victims, caring for their safety and privacy, and ensuring confidentiality ${ }^{(16)}$. It also involves defining which questions are necessary to clarify the situation, who should ask them, how to ask them, avoiding being judgmental, and which information to pass on to other team members ${ }^{(16)}$. It is equally necessary to problematize the meaning of violence against women ${ }^{(16)}$, as well as the protective legislation and community resources that can and should be accessed in these situations ${ }^{(21)}$.

Furthermore, the NT and CHA contextualized the term fear as a feeling that the victim and the professionals themselves have for the aggressor. A study identified the presence of this feeling in the $\mathrm{CN}$ of the social representation of health professionals, including the CHA, linking it to the professionals and victims ${ }^{(7)}$. The power relationship between offenders and victims may generate fear, causing them to live in constant alert. Fear and stigma permeate the process of reporting episodes of violence, because many victims want to protect their family from the ridiculous, by not revealing the situation ${ }^{(22)}$. It is important that health professionals show themselves available, and when the victims show the will or need to talk about the violent situation, they know who to resort to ${ }^{(16)}$.

The NT and CHA mentioned revolt as a feeling that may result from the support given to victims to encourage them to leave the violent situation, which often results in reconciliation and maintenance of violence. Thus, this phenomenon is difficult both for victims as for the professionals involved in the care. Among them, particularly the physicians sometimes do not inquire women about the occurrence of violence because they feel unable to solve the problem and realize that women are unable to follow their advice and change the situation ${ }^{(16)}$.

Revolt is a feeling also cultivated by health professionals in face of any violent act against women, often because they have already been through similar situations. Still, it may indicate that the NT and CHA are aware of the need to modify and create intervention strategies with the group of women in their community, although the victims often do not wish to. A study shows that physicians face barriers to investigate whether the woman has suffered violence, such as lack of time, support, training, fear of offending her, among others ${ }^{(16)}$.

Low self-esteem and submission refer to how the professionals visualize the victim. Another study with health professionals, including the CHA, also identifies the term submission in the first periphery of representation ${ }^{(7)}$. Cultural and patriarchal issues may lead health professionals to associate victims of violence and submission. It is noteworthy that the training curriculum of these professionals began to integrate issues on violence against women and family slowly ${ }^{(16)}$. We highlight a study that supports the premise that education of health professionals must meet the needs of patients first, but the sensations of vulnerability and fear also need to be addressed in order that the care for victims of violence is effective ${ }^{(21)}$.

Professionals associate the term pain to the victims' feelings about their body feeling as a consequence of physical aggression. The results of a study showed that among women who suffered physical violence, the majority reported bruises and body aches, as well as broken bones and injuries ${ }^{(18)}$.

The NT and CHA also verbalized bumiliation, suffering and sadness in the contrast area, as feelings generated in themselves and the victims, due to the occurrence of domestic violence against women. The aggressor initiates the process of violence with small deprivations, then causes situations of embarrassment and humiliation. Such situations may result from power relations between men and women. It is believed that contact with women and children facing such experiences negatively affects the health and life perspective of health professionals, and also of those indirectly dealing with the situation, such as receptionists, supervisors and managers ${ }^{(21)}$.

The elements of contrast area are considered important and possibly reinforce the constant ideas in the first periphery, or reveal the existence of a minority subgroup that has a different representation ${ }^{(23)}$. In the present study, was identified the existence of two subgroups with representations that contain variations. However, such variation does not change the central elements nor the own representation of the totality of informants ${ }^{(23)}$.

In this study, abuse and abuse of power were listed by the NT and CHA to judge the actions of offenders. A study shows that the power the perpetrator believes to have over the victim is identified by his control over her access to friends, health care and places like markets ${ }^{(19)}$. Another study points out that the fact of the wife being disobedient or arguing with her husband is a motive for physical violence $^{(24)}$.

At first, the term impunity refers to the small or delayed resolve of measures to punish the offender. However, in the context of the statements of the NT and CHA, impunity is associated to the fact of victims requesting the support of the health team to denounce the aggressor, but then giving up the idea or even withdrawing the complaint. It is noteworthy that before providing assistance to the victim, the health professionals as a team, should identify support services, safe spaces in the community, mobilize local leaders and social actions, interventions for offenders, shelters for victims, and 
contact with non-governmental organizations ${ }^{(16)}$. The professionals must also reflect about their ability to provide care for victims of violence, as not all may be willing and able to do it, so it is essential to know the appropriate providers of the services, care and ongoing support ${ }^{(21)}$.

\section{CONCLUSION}

The social representation of the NT and CHA about domestic violence against women has a negative connotation, identified by the terms abuse, aggression, physical aggression, cowardice and lack of respect. It is a structured representation, as it presents conceptual, imaging, and attitudinal elements.

Two subgroups are identified; one consists of professionals working in the FHU of the rural area, and another one consists only of CHA. The CN of the first subgroup has the terms suffering and sadness, with the latter also included in the $\mathrm{CN}$ of the second subgroup. The maximum tree obtained by similarity analysis shows that the term $a g-$ gression is the organizer of other elements of representation. From it, are established connections with the other terms, considering that the highest index is with the term physical aggression.

The results of this study are the first analysis of a specific group of health professionals, pointing out that the phenomenon of domestic violence against women needs to be further investigated, expanding to other professions and locations. We emphasize the difficulty of discussing these results, because of the small number of scientific publications on the subject of this study.

We believe that the knowledge of the social representations of the NT and CHA about domestic violence against women allows the problematization of this phenomenon with the team, and facilitates the search for prevention and intervention strategies for victims, attackers and managers of health services.

\section{RESUMO}

Objetivo: Analisar as representações sociais dos Técnicos de Enfermagem e Agentes Comunitários de Saúde acerca da violência doméstica contra a mulher. Método: Estudo qualitativo desenvolvido no Município do Rio Grande, RS, cujas evocações e entrevistas foram colhidas entre os meses de julho a novembro de 2013. Para o tratamento dos dados utilizou-se o software EVOC 2005 e a análise de contexto. Resultados: Percebeu-se que se trata de uma representação estruturada, cujo núcleo central contém elementos conceituais, imagéticos e atitudinais, sendo eles abuso, agressão, agressão física, covardia e falta de respeito. Tais termos fizeram-se presentes no contexto das entrevistas. Os profissionais reconheceram que a violência não se limita a aspectos físicos e expressaram julgamento frente aos atos do agressor. Conclusão: Acredita-se que este conhecimento possibilite a problematização do fenômeno estudado com a equipe, bem como facilite a busca de estratégias de prevenção e intervenção junto às vítimas, agressores e gestores dos serviços de saúde.

\section{DESCRITORES}

Violência Contra a Mulher; Violência Doméstica; Agentes Comunitários de Saúde; Papel do Profissional de Enfermagem; Cuidados de Enfermagem.

\section{RESUMEN}

Objetivo: Analizar las representaciones sociales de los Técnicos de Enfermería y Agentes Comunitarios de Salud acerca de la violencia doméstica contra la mujer. Método: Estudio cualitativo desarrollado en el Municipio de Rio Grande, RS, cuyas evocaciones y entrevistas fueron recogidas entre los meses de julio y noviembre de 2013. Para el tratamiento de los datos se utilizó el software EVOC 2005 y el análisis de contexto. Resultados: Se advirtió que se trata de una representación estructurada, cuyo núcleo central contiene elementos conceptuales, de imagen y de actitud, que son el abuso, la agresión, la agresión física, la cobardía y la falta de respeto. Dichos términos estuvieron presentes en el marco de las entrevistas. Los profesionales reconocieron que la violencia no se limita a los aspectos físicos, y expresaron su juicio ante los actos del agresor. Conclusión: Se cree que ese conocimiento posibilite la problematización del fenómeno estudiado con el equipo, así como facilite la búsqueda de estrategias de prevención e intervención junto a las víctimas, agresores y gestores de los servicios de salud.

\section{DESCRIPTORES}

Violencia Contra la Mujer; Violencia Doméstica; Agentes Comunitarios de Salud; Rol de la Enfermera; Atención de Enfermería.

\section{REFERENCES}

1. World Health Organization. WHO report highlights violence against women as a 'global health problem of epidemic proportions' [Internet]. Geneva; 2013 [cited 2013 Oct 14]. Available from: http://www.who.int/mediacentre/news/releases/2013/violence_against_women_20130620/en/

2. Waiselfisz JJ. Mapa da violência 2012. Atualização: homicídio de mulheres no Brasil [Internet]. São Paulo: FLACSO; 2012 [citado 2013 out. 14]. Disponível em: http://mapadaviolencia.org.br/pdf2012/MapaViolencia2012_atual_mulheres.pdf

3. Brasil. Lei n. 11.340, de 7 de agosto de 2006. Cria mecanismos para coibir a violência doméstica e familiar contra a mulher [Internet]. Brasília; 2006 [citado 2013 out. 14]. Disponível em: http://www.planalto.gov.br/ccivil_03/_ato2004-2006/2006/lei/l11340.htm

4. Silva RA, Araujo TVB, Valongueiro S, Ludermir AB. Facing violence by intimate partner: the experience of women in an urban area of Northeastern Brazil. Rev Saúde Pública. 2013;46(6):1014-22.

5. Hesler LZ, Costa MC, Resta DG, Colomé ICS. Violence against women in the perspective of community health agents. Rev Gaúcha Enferm. 2013;34(1):180-6. 
6. Brasil. Lei n. 11.350, de 5 de outubro de 2006. Regulamenta o $\S 5^{\circ}$ do art. 198 da Constituição, dispõe sobre o aproveitamento de pessoal amparado pelo parágrafo único do art. $2^{\circ}$ da Emenda Constitucional no 51, de 14 de fevereiro de 2006, e dá outras providências [Internet]. Brasília; 2006 [citado 2013 out. 14]. Disponível em: http://www.planalto.gov.br/ccivil_03/_ato2004-2006/2006/lei/l11350.htm

7. Costa MC, Lopes MJM, Soares JSF. Social representations of violence against rural women: unveiling senses in multiple views. Rev Esc Enferm USP. 2014;48(2):213-21.

8. Jodelet D. As representações sociais. Rio de Janeiro: Ed. UERJ; 2001.

9. Abric JC. A abordagem estrutural das representações sociais. In: Moreira ASP, Oliveira DC, organizadoras. Estudos interdisciplinares de representação social. Goiânia: AB; 1998. p. 27-38.

10. Santos EI, Gomes AMT, Oliveira DC. Representations of vulnerability and empowerment of nurses in the context of HIV/AIDS. Texto Contexto Enferm. 2014; 23(2):408-16.

11. Pontes APM, Oliveira DC, Gomes AMT. The principles of the Brazilian Unified Health System studied based on similitude analysis. Rev Latino Am Enfermagem. 2014;22(1):59-67.

12. Sá CP. Núcleo central das representações sociais. $2^{a}$ ed. Petrópolis: Vozes; 2002.

13. Bardin L. Análise de conteúdo. Lisboa: Edições 70; 2011.

14. Moscovici S. A psicanálise, sua imagem e seu público. 2ª ed. Petrópolis: Vozes; 2012.

15. Nascimento EFGA, Ribeiro AP, Souza ER. Perceptions and practices of Angolan health care professionals concerning intimate partner violence against women. Cad Saúde Pública [Internet]. 2014 [cited 2014 Oct 25];30(6):1229-38. Available from: http://www.scielosp. org/pdf/csp/v30n6/0102-311X-csp-30-6-1229.pdf

16. Garcia-Moreno C. Dilemmas and opportunities for an appropriate health-service response to violence against women. Lancet. 2002;359(9316):1509-14.

17. Al-Atrushi HH, Al-Tawil NG, Shabila NP, Al-Hadithi TS. Intimate partner violence against women in the Erbil city of the Kurdistan region, Iraq. BMC Womens Health [Internet]. 2013 [cited 2014 Jan 24];13:37. Available from: http://www.ncbi.nlm.nih.gov/pmc/articles/ PMC3852841/.

18. Semahegn A, Belachew T, Abdulahi M. Domestic violence and its predictors among married women in reproductive age in Fagitalekoma Woreda, Awi zone, Amhara regional state, North Western Ethiopia. Reprod Health [Internet]. 2013 [cited 2014 Jan 23];10:63. Available from: http://www.ncbi.nlm.nih.gov/pmc/articles/PMC3879008/

19. Mishra A, Patne SK, Tiwari R, Srivastava DK, Gour N, Bansai M. A cross-sectional Study to find out the prevalence of different types of domestic violence in Gwalior city and to identify the various risk protective factors for domestic violence. Indian J Community Med [Internet]. 2014 [cited 2014 Apr 15];39(1):21-5. Available from: http://www.ncbi.nlm.nih.gov/pmc/articles/PMC3968576/.

20. Vieira EM, Ford NJ, De Ferrante FG, Almeida AM, Daltoso D, Santos MA. The response to gender violence among Brazilian health care professionals. Ciênc Saúde Coletiva. 2013;18(3):681-90.

21. Coles J, Dartnall E, Astbury J. "Preventing the pain" when working with family and sexual violence in primary care. Int J Fam Med [Internet]. 2013 [cited 2014 Aug 11]. Available from: http://www.ncbi.nlm.nih.gov/pmc/articles/PMC3600345/

22. Oliveira DC, Marques SC, Gomes AMT, Teixeira MCTV. Análise das evocações livres: uma técnica de analise estrutural das representações sociais. In: Moreira ASP, organizador. Perspectivas teórico-metodológicas em representações sociais. João Pessoa: UFPE Ed. Universitária; 2005. p. 573-603.

23. Bibi S, Ashfaq S, Shaikh F, Qureshi PM. Prevalenceinstigating factors and help seeking behavior of physical domestic violence among married women of HyderabadSindh. Pak J Med Sci [Internet]. 2014 [cited 2014 Apr 13];30(1):122-5. Available from: http://www.ncbi. nlm.nih.gov/pmc/articles/PMC3955555/

24. Stockman JK, Lucea MB, Bolyard R, Bertand D, Callwood GB, Sharps PW, et al. Intimate partner violence among African American and African Caribbean women: prevalence, risk factors, and the influence of cultural attitudes. Glob Health Action. 2014 [cited 2014 Oct 26];7:24772. Available from: http://www.ncbi.nlm.nih.gov/pubmed/25226418 